\title{
Effects of Gamma Radiation on the Conformational and Antigenic Properties of a Heat-Stable Major Allergen in Brown Shrimp
}

\author{
MYUNG-WOO BYUN, ${ }^{*}$ JAE-HUN KIM, ${ }^{1}$ JU-WOON LEE, ${ }^{1}$ JUNG-WON PARK, ${ }^{2}$ CHEIN-SOO HONG, ${ }^{2}$ AND \\ IL-JUN KANG ${ }^{3}$
}

\footnotetext{
${ }^{1}$ The Team for Radiation Food Science and Biotechnology, Korea Atomic Energy Research Institute, P.O. Box 105, Yusong, Taejon, 305-600, Korea; ${ }^{2}$ Institute of Allergy, College of Medicine, Yonsei University, Seoul, 120-749, Korea; and ${ }^{3}$ Division of Life Science, Hallym University,
} Chunchon, 200-702, Korea

MS 99-341: Received 10 November 1999/Accepted 11 February 2000

\begin{abstract}
This study was performed to evaluate the application of food irradiation technology as a method for reducing shrimp allergy without adverse effects. Shrimp heat-stable protein (HSP) was isolated and gamma irradiated at $0,1,3,5,7$, or 10 $\mathrm{kGy}$ in the condition of solution $(1 \mathrm{mg} / \mathrm{ml})$, and fresh shrimp was also irradiated. Conformational change of irradiated HSP was monitored by means of spectrometric measures, enzyme-linked immunosorbent assay with mouse monoclonal antibody, or human patients' sera and sodium dodecyl sulfate-polyacrylamide gel electrophoresis. The ability of the immunoglobulin $\mathrm{E}$ of patients allergic to shrimp to bind to irradiated HSP was dose dependently reduced. The amount of intact HSP in an irradiated solution was reduced by gamma irradiation, depending on the dose. Sodium dodecyl sulfate-polyacrylamide gel electrophoresis showed that the main band disappeared and the traces induced from coagulation appeared at a higher molecular weight zone. The binding ability of immunoglobulin $\mathrm{E}$ to allergens in the extracts from irradiated shrimp decreased, depending on the dose. The results provide a new method so that food irradiation technology can be applied to reduce allergenicity of shrimp.
\end{abstract}

The hydrolysis of allergens by enzymes and development of recombinant foods with modified DNA have been studied to eliminate protein allergens from allergenic foods $(2,3,26)$. These approaches can be used only in extremely limited foodstuffs. There have been several investigations into the changes in proteins caused by irradiation treatments $(1,10,12,29)$. The irradiation technique was used in several studies to reduce egg or milk allergy $(15,16,19)$. Research and development of food irradiation during about four decades have shown that foods irradiated with an average dose of $10 \mathrm{kGy}$ are safe for human consumption without any toxicological hazard and any special nutritional or microbiological problems $(11,27,30)$.

Shrimp is one of the most common allergenic foods $(5,9,31)$. Since muscle tropomyosin was reported as the major allergen among shrimp allergens, many researchers have indicated that the protein is a heat-stable protein (HSP) with molecular weight of $36 \mathrm{kDa}$ (Pen a 1 from Penaeus aztecus $(6-8,22)$ ) or of $34 \mathrm{kDa}$ (Pen i I from Penaeus indicus (24) and Met e I from Metapenaues ensis (20)). In the previous study (18), surface epitopes on muscle myosin could be changed by gamma irradiation doses of less than $5 \mathrm{kGy}$.

In this study, we investigate whether the structure of HSP is modified by ionizing radiation and whether irradi-

\footnotetext{
* Author for correspondence. Tel: 82.42.868.8065; Fax: 82.42.868.8043; E-mail: mwbyun@nanum.kaeri.re.kr.
}

ation technology can be used to reduce shrimp-induced food allergy.

\section{MATERIALS AND METHODS}

Human sera and animal anti-HSP antibodies. Human sera were obtained from 20 patients with immediate hypersensitivity reactions after ingestion of cooked shrimp. All patients had a positive skin prick test reaction to shrimp Ag extract and had serum immunoglobulin E (IgE) antibodies specific for the major shrimp allergen Pen a 1. Sera collected from five healthy subjects with no history of atopy served as negative controls. Mouse monoclonal antibody (mAb) 4.9.5 produced previously (14) was also used for competitive indirect enzyme-linked immunosorbent assay (ELISA).

Shrimp and preparation of major HSP ( $36 \mathrm{kDa})$. One portion of fresh brown shrimp ( $P$. aztecus) was used to prepare HSP and another was vacuum-packaged for irradiating. Major HSP of shrimp was prepared by a modification of the method described previously $(7,14)$. Briefly, fresh shrimp were boiled for $15 \mathrm{~min}$ in ion-depleted water, peeled, and deveined. The boiled meat was homogenized in phosphate-buffered saline (PBS, $0.01 \mathrm{M}$ phosphate buffer, $0.15 \mathrm{M} \mathrm{NaCl}, \mathrm{pH}$ 7.2). The mixture was stirred overnight at $4^{\circ} \mathrm{C}$ and centrifuged at $10,000 \mathrm{rpm}$ for $30 \mathrm{~min}$. The supernatant was filtered through Whatman no. 3 filter paper. Solid $\left(\mathrm{NH}_{4}\right)_{2} \mathrm{SO}_{4}$ was added into the filtrate as $30 \%$ saturation, and the solution was centrifuged at $6,000 \mathrm{rpm}$ for $20 \mathrm{~min}$. Solid $\left(\mathrm{NH}_{4}\right)_{2} \mathrm{SO}_{4}$ was added into the supernatant as $60 \%$ saturation, and the solution was centrifuged. Precipitate was dissolved into PBS and dialyzed overnight into the same buffer with several changes. The dialyzed solution was filtered through $0.45-\mu \mathrm{m}$ filter paper. 
The filtrate was isoelectric precipitated at $\mathrm{pH} 4.5$ with $0.1 \mathrm{~N} \mathrm{HCl}$ and centrifuged at $8,000 \mathrm{rpm}$ for $20 \mathrm{~min}$, and precipitate was redissolved with PBS. Isoelectric precipitation was repeated three times. Redissolved solution was dialyzed into PBS. Protein concentration was determined by using a bicicinchonic acid (BCA) protein assay kit (Sigma Chemical Co., St. Louis, Mo.) with bovine serum albumin solution as a standard and adjusted to $1.0 \mathrm{mg} /$ $\mathrm{ml}$ (25). A total of $10 \mathrm{ml}$ of HSP solution was put into a glass tube $(\phi 1 \mathrm{~cm})$ with cap and irradiated at the designated doses. The remaining solution was mixed with an equal volume of glycerol and stored at $-20^{\circ} \mathrm{C}$ until used.

Gamma irradiation. Gamma irradiation was carried out in a cobalt-60 irradiator equipped with $100 \mathrm{kCi}$ activity at $10 \pm$ $0.5^{\circ} \mathrm{C}$ and operated at a dose rate of $10 \mathrm{kGy} \mathrm{h}^{-1}$. The applied dose levels were 0 (control), 1, 3, 5, 7, and $10 \mathrm{kGy}$. The absorbed dose was monitored with both free radical and ceric or cerous dosimeters. After irradiation, HSP solutions and irradiated shrimps were stored at $4^{\circ} \mathrm{C}$ in a low-temperature incubator (MIR 552; Sanyo Co., Osaka, Japan) until used.

Turbidity, surface hydrophobicity, and colorimetric reaction of irradiated HSP solution. Turbidity and protein concentration of an irradiated HSP solution were determined by tests of absorbance at $280 \mathrm{~nm}$ and by BCA assay at $562 \mathrm{~nm}$ with a spectrophotometer (UV-1600PC; Shimadzu Corp., Kyoto, Japan). The surface hydrophobicity value of irradiated HSP solution was measured to monitor the structural changes. HPS-1-anilinonaphthalene-8-sulfonate (ANS) hydrophobicity was determined by the method described previously (28). A total of $20 \mu \mathrm{l}$ of ANS solution ( $8 \mathrm{mM}$ in $0.01 \mathrm{M}$ PBS, $\mathrm{pH} 7.4$ ) was added to HSP solutions $(1.0 \mathrm{mg} / \mathrm{ml})$ of $4 \mathrm{ml}$. The relative fluorescence intensity of ANS-HSP complex was measured at excitation and emission wavelengths of 385 and $470 \mathrm{~nm}$, respectively, with a spectrofluorophotometer (RF-5301PC; Shimadzu, Kyoto, Japan).

Preparation of muscle protein solutions from irradiated shrimp. Shrimp muscle extracts were prepared from irradiated and peeled muscle. Two grams of sample was homogenized within $20 \mathrm{ml}$ of cold PBS. The homogenate was centrifuged at 10,000 rpm for $20 \mathrm{~m}$ at $4^{\circ} \mathrm{C}$, and supernatant was filtered through Whatman no. 3 filter paper to remove insoluble particles. Filtrates were used as a sarcoplasmic protein solution. The remaining precipitate was washed three times with a cold PBS and recentrifuged. The precipitate was redissolved in $20 \mathrm{ml}$ of a cold high-salt buffer $(0.6$ $\mathrm{M} \mathrm{NaCl}, 0.01 \mathrm{M}$ phosphate buffer, $\mathrm{pH}$ 7.0) by homogenizing. The homogenate was centrifuged at $10,000 \mathrm{rpm}$ for $20 \mathrm{~min}$ at $4{ }^{\circ} \mathrm{C}$, and the supernatant was filtered through Whatman no. 3 filter paper to remove insoluble particles. The filtrates were used as a myofibrillar protein solution. Protein concentration of the solutions was determined by the BCA protein assay kit. The filtrate was used to test the binding ability of patients' IgE to allergens and of mAb 4.9.5 to antigen, respectively. Nonirradiated shrimp was used as the control.

Competitive indirect ELISA with patients' IgE or mAb 4.9.5. The binding ability of IgE in the patients' sera pool to the irradiated HSP or to the shrimp protein fractions was tested by competitive indirect ELISA (18). Briefly, polystyrene flat-bottom microtiter plates (Maxisorp, Nunc, Kamstrup, Denmark) were coated with $1 \mu \mathrm{g} / \mathrm{ml}$ of HSP in a $0.2 \mathrm{M}$ bicarbonate buffer, $\mathrm{pH}$ 9.6, overnight at $4^{\circ} \mathrm{C}$. All subsequent steps were performed at $37^{\circ} \mathrm{C}$. Plates were washed three times with PBS containing $0.05 \%$ (vol/vol) Tween 20 (PBST). To reduce nonspecific binding, the plates were blocked by incubation for $1.5 \mathrm{~h}$ with $120 \mu \mathrm{l}$ of PBS containing $1 \%(\mathrm{wt} / \mathrm{vol})$ bovine serum albumin and washed three times with PBST. A total of $50 \mu$ of sample solution 50-fold diluted with PBS and $50 \mu \mathrm{l}$ of IgE solution were added to five coated and blocked wells, respectively. Plates were incubated for $1.5 \mathrm{~h}$ and then washed three times with PBST. After the addition of $100 \mu \mathrm{l}$ of 1:1,000 diluted horseradish peroxidase-conjugated rabbit anti-human IgE-IgG solution (Sigma) to the wells, the plates were incubated for $1.5 \mathrm{~h}$. After washing three times, 100 $\mu \mathrm{l}$ of $0.04 \%$ o-phenylenediamine (Sigma) in $0.1 \mathrm{M}$ phosphate citrate buffer, $\mathrm{pH} 5.0$, with $0.04 \%$ hydrogen peroxide (vol/vol, $35 \%$ $\mathrm{H}_{2} \mathrm{O}_{2}$ ) was added for running the color reaction for $20 \mathrm{~min}$ before stopping it with $2.0 \mathrm{M} \mathrm{H}_{2} \mathrm{SO}_{4}(50 \mu \mathrm{l} /$ well). Absorbance was measured at $492 \mathrm{~nm}$ by an ELISA reader (CERES UV-900C; BIOTEK Instruments Inc., New York, N.Y.).

Following the above procedure, the binding ability of mAb 4.9.5 to the irradiated HSP or to the shrimp protein fractions was also tested with horseradish peroxidase-conjugated rabbit antimouse IgG as secondary antibody.

Standard curves for patients' IgE and for mAb 4.9.5 were obtained in the range of 0.01 to $10 \mu \mathrm{g} / \mathrm{ml}$ of HSP. The concentration of HSP in the sample was determined on a standard curve.

Sodium dodecyl sulfate-polyacrylamide gel electrophoresis (SDS-PAGE). SDS-PAGE (5 to $15 \%$ gradient gel) for irradiated HSP solutions ( $1 \mathrm{mg} / \mathrm{ml}$ ) was performed by Laemmli's method (17) using a Hoefer vertical electrophoresis apparatus SE-260 (Hoefer Scientific Instruments, San Francisco, Calif.), and staining and destaining were done as described previously (4). A molecular weight marker was purchased from Pharmacia Biotech (Uppsala, Sweden) to determine the molecular weights. The marker contains phosphorylase b (94 kDa), albumin (67 kDa), ovalbumin (43 $\mathrm{kDa})$, carbonic anhydrase (30 kDa), trypsin inhibitor (20.1 kDa), and $\alpha$-lactalbumin $(14.4 \mathrm{kDa})$.

Statistical analysis. All samples were done in triplicate, and the experiments were repeated five times. Means and standard deviations were used to evaluate binding abilities of antibodies to HSP and spectrometric results. Data were analyzed by the general linear procedures, least-squares means, and the Duncan multiple range test. SAS statistical software (23) was used to perform the above mentioned studies.

\section{RESULTS AND DISCUSSION}

Turbidity, surface hydrophobicity, and colormetric reaction of irradiated HSP solution. Muscle tropomyosin is a 41-nm-long, rod-shaped molecule similar to the myosin tail and a dimer of identical $\alpha$-helical chains (284 amino acids each), which wind around each other in a coil (21, 24). Table 1 indicates the results of the turbidity, surface hydrophobicity, and colormetric reaction of the irradiated HSP solution. The turbidity of the irradiated HSP solution increased, depending on the increase of the dose, when observed by a spectrophotometer $(280 \mathrm{~nm})$. Relative fluorescence intensity of irradiated HSP also increased, depending on the dose, and showed a maximum value between 5 and $7 \mathrm{kGy}$. However, there were no significant differences in the protein concentration in irradiated HSP solution when determined by the BCA method. These results indicate that the coiled structure is released and hydrophobic amino acids are exposed to the outside by gamma irradiation, as a process in other proteins with $\alpha$-helical chains $(12,18,31)$.

Binding abilities of $\mathrm{mAb}$ 4.9.5 and patients' IgE. The amount of HSP in the irradiated solutions was deter- 
TABLE 1. Turbidity, surface hydrophobicity, and colorimetric reaction by bicicinchonic acid assay of irradiated shrimp heat-stable protein solutions $(1-\mathrm{mg} / \mathrm{ml})^{a}$

\begin{tabular}{lcccccc}
\hline & \multicolumn{5}{c}{ Irradiation dose (kGy) } \\
\cline { 2 - 6 } & 0 & 1 & 3 & 5 & 7 & 10 \\
\hline OD value at $280 \mathrm{~nm}$ & $1.912 \mathrm{~A}^{b}$ & $2.043 \mathrm{~B}$ & $2.164 \mathrm{C}$ & $2.305 \mathrm{D}$ & $2.352 \mathrm{E}$ & $2.397 \mathrm{~F}$ \\
Surface hydrophobicity (RFI) & $1.376 \mathrm{~A}$ & $2.589 \mathrm{~B}$ & $3.368 \mathrm{C}$ & $3.582 \mathrm{D}$ & $3.591 \mathrm{D}$ & $3.326 \mathrm{CE}$ \\
OD value at $562 \mathrm{~nm}$ & $0.289 \mathrm{~A}$ & $0.284 \mathrm{~A}$ & $0.291 \mathrm{~A}$ & $0.296 \mathrm{~A}$ & $0.295 \mathrm{~A}$ & $0.301 \mathrm{~B}$ \\
\hline
\end{tabular}

${ }^{a}$ A total of $10 \mathrm{ml}$ of heat-stable protein solution was irradiated at the designated dose and individually measured at the experiment items.

${ }^{b}$ Means in the same row with unlike letters differ significantly $(P \leq 0.05)$.

mined by competitive indirect ELISA. The detected concentration decreased dependent on the increase of the dose (Fig. 1). The results of competitive indirect ELISA with $\mathrm{mAb}$ indicate that antigenic properties of irradiated HSP were changed by gamma irradiation.

Patients' shrimp-specific IgE did not recognize the irradiated HSP as well at higher doses (Fig. 1). Figure 1 shows $50 \%$ less binding to $\operatorname{IgE}$ at $3 \mathrm{kGy}$; this is not necessarily the same as $50 \%$ of intact HSP. In the solution irradiated with $10 \mathrm{kGy}, 18.5 \%$ of HSP was only detected. The correlation coefficient between the results from $\mathrm{mAb}$ 4.9.5 and human IgE was 0.9650 at $P \leq 0.05$. These results indicate that IgE-mediated hypersensitivity from shrimp was reduced by gamma irradiation, when approached with the proper dose.

There are several factors on denaturation of protein in aqueous solutions by radiation, and the factors are the local conformation of an amino acid in the peptide chain, its accessibility to the water radiolysis products, and the amino acid sequence itself, where some particular amino acid residues may be more susceptible to radiolysis (10).

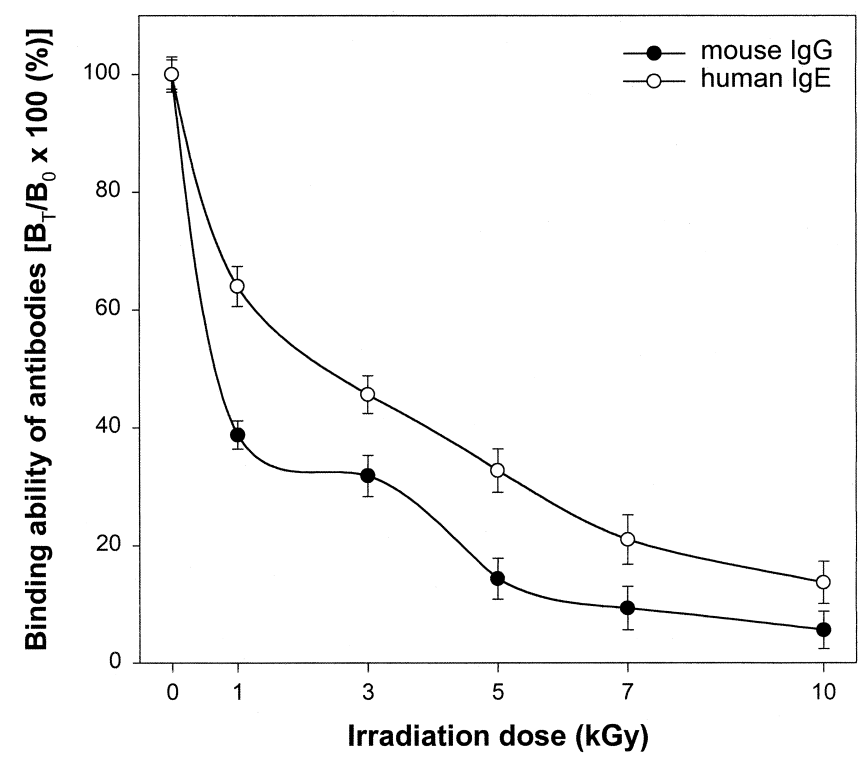

FIGURE 1. Binding abilities of mouse immunoglobulin $G(\operatorname{IgG})$ (monoclonal antibody 4.9.5) and patients' IgE to gamma-irradiated heat-stable protein (HSP). The binding ability was measured by competitive indirect enzyme-linked immunosorbent assay. $B_{T}$ and $B_{0}$ indicate binding ability of irradiated HSP and that of nonirradiated $H S P$, respectively.
SDS-PAGE. From SDS-PAGE (5 to $15 \%$ gradient gel) of the irradiated HSP, it appeared that the main band (36 $\mathrm{kDa}$ ) disappeared more and more, depending on the dose, and was not detected at the doses of $5 \mathrm{kGy}$ and above (Fig. 2). The molecular weight of the detected band of HSP irradiated with $1 \mathrm{kGy}$ was slightly higher than that of the control. It was observed that traces spread from the starting line of separating gel at the doses of $3 \mathrm{kGy}$ or more. By gamma irradiation, a protein molecule can be broken down to smaller molecules or coagulated to larger molecules by interaction among the molecules (12). The HSP of shrimp was coagulated by gamma irradiation. This result was similar to the changes of irradiated muscle myosin (18). These changes in irradiated protein cause the reactions of antibody to be changed.

Binding ability of patients' IgE to irradiated shrimp muscle solutions. Patients' IgE recognized allergens in both sarcoplasmic protein fraction and myofibrillar protein fraction extracted from brown shrimp (Fig. 3). Binding ability of patients' IgE to both protein fractions decreased, depending on the dose. At $10 \mathrm{kGy}$, the binding ability of

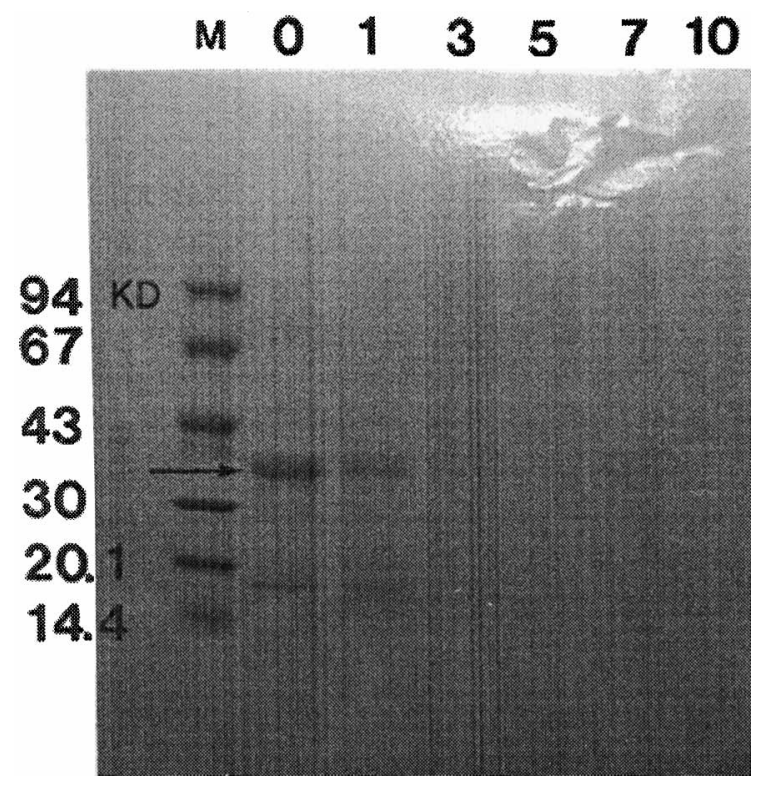

FIGURE 2. Sodium dodecyl sulfate-polyacrylamide gel electrophoresis (5 to $15 \%$ gradient acrylamide gel) of the irradiated shrimp heat-stable protein $(1 \mathrm{mg} / \mathrm{ml}) . M$ and numerals indicate molecular weight standard and the irradiation doses ( $k G y)$, respectively. Arrow indicates main band (36 kDa). 


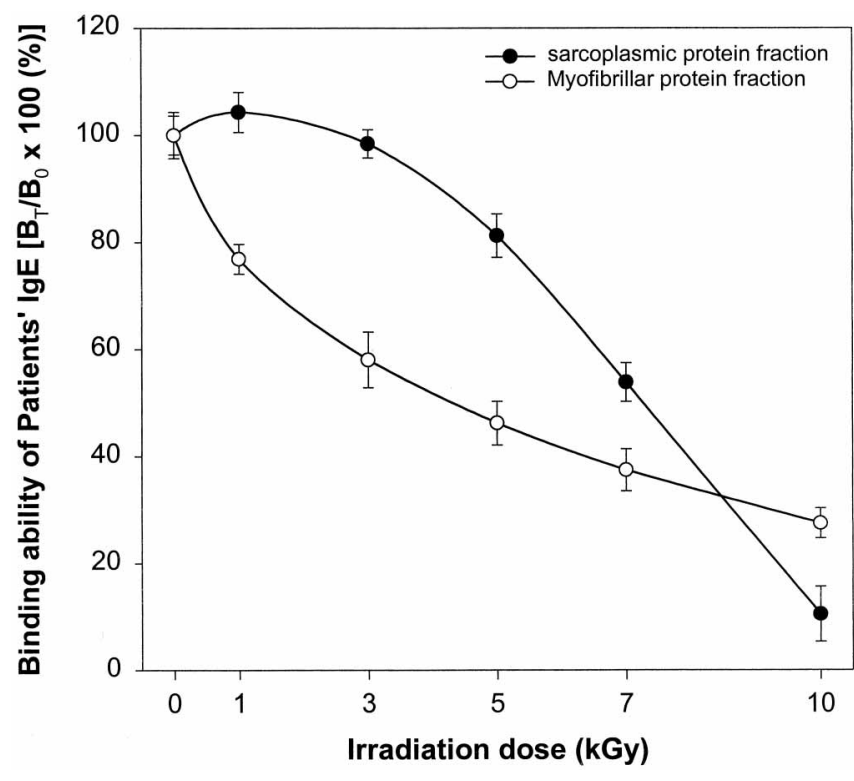

FIGURE 3. Binding ability of patient's immunoglobulin $E$ to allergens in gamma-irradiated shrimp extracts. The binding ability was measured by competitive indirect enzyme-linked immunosorbent assay. $B_{T}$ and $B_{0}$ indicate binding ability of irradiated heatstable protein and that of nonirradiated heat-stable protein, respectively.

patients' IgE was below $30 \%$ in both protein fractions. It is clinically important to compare the differences of the reactivities of patients' $\mathrm{IgE}$ to isolated and then irradiated HSP with those of IgE to irradiated shrimp. At the evaluation on the effects of gamma irradiation to the whole shrimp muscle, binding ability of patients' IgE to allergens in two protein fractions decreased, depending on the dose. Of note, IgE-specific allergens existed in both fractions. Patients' IgE used in this study might recognize not only other allergens but also tropomyosin (3). The conformational modification of allergens was caused by gamma irradiation at the shrimp muscle. At doses above $7 \mathrm{kGy}$, the binding ability of patients' IgE was below $50 \%$ at both fractions. Thayer (27) reported that macronutrients (proteins and fats) of irradiated foods were not significantly altered in terms of nutrient value and digestibility by irradiation treatment doses of $10 \mathrm{kGy}$ and less. This result indicates that the reduction of antigenicities of shrimp allergens is generated by gamma irradiation with adequate dose, which is permitted in food irradiation (13).

\section{ACKNOWLEDGMENT}

This project has been performed under the Nuclear Research \& Development Program of the Korea Ministry of Science and Technology.

\section{REFERENCES}

1. Al-kahtani, H. A., H. M. Abu-tarbouch, M. Atia, A. S. Bajaber, M. A. Ahmed, and M. A. El-mojaddidi. 1998. Amino acid and protein changes in tilapia and spanish mackerel after irradiation and storage. Radiat. Phys. Chem. 51:107-114.

2. Asselin, A., J. Hebert, and J. Amiot. 1989. Effects of in vitro proteolysis on the allergenicity of major whey proteins. J. Food Sci. 54: 1037-1039.

3. Astwood, J. D., R. L. Fuchs, and P. B. Lavrik. 1997. Food biotech- nology and genetic engineering, p. 65-92. In D. D. Metcalfe, H. A. Sampson, and R. A. Simon (ed.), Food allergy: adverse reactions to food and food additives. Blackwell Scientific Publications, Boston.

4. Claeys, E., U. R. Buts, and D. Demeyer. 1995. Quantification of beef myofibrillar proteins by SDS-PAGE. Meat Sci. 39:177-193.

5. Daul, C. B., J. E. Morgan, and M. L. McCants. 1987. Crustacea allergy: immunologic evaluation shrimp-allergic individuals. J. Allergy Clin. Immunol. 80:716-721.

6. Daul, C. B., M. Slattery, J. E. Morgan, and S. B. Lehrer. 1991. Isolation and characterization of important $36 \mathrm{kD}$ shrimp allergen [abstract]. J. Allergy Clin. Immunol. 87:192.

7. Daul, C. B., M. Slattery, J. E. Morgan, and S. B. Lehrer. 1994. Common crustacea allergens: identification of B cell epitopes with the shrimp specific monoclonal antibodies, p. 291-294. In D. Kraft, and A. Sehen (ed.), Molecular biology and immunology of allergens. CRC Press, Boca Raton, Fla.

8. Daul, C. B., M. Slattery, G. Reese, and S. B. Lehrer. 1994. Identification of the major brown shrimp (Penaeus aztecus) allergen as the muscle protein tropomyosin. Int. Arch. Allergy Immunol. 105: 49-55.

9. David, T. J. 1993. Food and food additive intolerance in childhood, p. 157-159. Blackwell Scientific Publications, Oxford.

10. Filali-mouhim, A., M. Audette, M. St-Louis, L. Thauvette, L. Denoroy, F. Penin, X. Chen, N. Rouleau, J. P. Le Caer, J. Rossier, M. Potier, and M. Le Maire. 1997. Lysozyme fragmentation induced by $\gamma$-radiolysis. Int. J. Radiat. Biol. 72:63-70.

11. Hackwood, S. 1994. An introduction to the irradiation processing of foods. In S. Throne (ed.), Food irradiation. Elsevier, London.

12. Horowits, R., E. S. Kempner, M. E. Bisher, and R. J. Podolsky. 1986. A physiological role for titin and nebulin in skeletal muscle. Nature 323:160-164.

13. International Atomic Energy Institute (IAEA). 1995. Shelf-stable foods through irradiation processing. IAEA-TECDOC-843. IAEA, Vienna.

14. Jeoung, B. J., G. Reese, P. Hauck, J. B. Oliver, C. B. Daul, and S. B. Lehrer. 1997. Quantification of the major brown shrimp allergen Pen a 1 (tropomyosin) by a monoclonal antibody-based sandwich ELISA. J. Allergy Clin. Immunol. 100:229-234.

15. Kume, T., and T. Matsuda. 1995. Changes in structural and antigenic properties of proteins by radiation. Radiat. Phys. Chem. 46:225-231.

16. Kume, T., T. Ishii, and T. Matsuda. 1994. Immunochemical identification of irradiated chicken eggs. J. Sci. Food Agric. 65:1-4.

17. Laemmli, U. K. 1970. Cleavage of structural proteins during the assembly of the head of bacteriophage T4. Nature 227:680-685.

18. Lee, J. W., H. S. Yook, K. H. Lee, J. H. Kim, and M. W. Byun. 1999. Conformational changes of myosin by gamma irradiation. Radiat. Phys. Chem., in press.

19. Lee, Y. K., S. Matsuhashi, and T. Kume. 1999. Change in carbohydrates of chicken and quail ovomucoids by gamma radiation. Radiat. Phys. Chem. 54:285-290.

20. Leung, P. S. C., K. H. Chu, W. K. Chow, A. Ansari, C. I. Bandea, H. S. Kwan, S. M. Nagy, and M. E. Gershwin. 1994. Cloning, expression, and primary structure of Metapenaeus ensis tropomyosin, the major heat-stable shrimp allergen. J. Allergy Clin. Immunol. 94: 882-890.

21. Phillips, G. N., J. P. Fillers, and C. Cohen. 1986. Tropomyosin crystal structure and muscle regulation. J. Mol. Biol. 192:111-131.

22. Reese, G., C. B. Daul, S. B. Lehrer. 1995. Antigenic analysis (IgE and $\mathrm{mABs}$ ) of the major shrimp allergen Pen a 1 (tropomyosin) from Penaeus aztecus. Int. Arch. Allergy Immunol. 107:245-247.

23. SAS Institute. 1988. SAS/STATTM user's guide, release 6.03 edition. SAS Institute Inc., Cary, N.C.

24. Shanti, K. L., B. M. Martin, S. L. Nagpal, D. D. Metcalfe, and P. V. Subba Rao. 1993. Identification of tropomyosin as the major shrimp allergen and characterization of its IgE-binding epitopes. J. Immunol. 151:5354-5363.

25. Smith, P. K., R. I. Krohn, G. T. Hermanson, A. K. Mallia, F. H. Gartner, M. D. Provenzano, E. K. Fujimoto, N. M. Goeke, B. J. Olson, and D. C. Klenk. 1985. Measurement of protein using bicinchoninic acid. Anal. Biochem. 150:76-85. 
26. Taylor, S. 1980. Food allergy: the enigma and some potential solutions. J. Food Prot. 43:300-306.

27. Thayer, D. W. 1990. Food irradiation: benefits and concerns. J. Food Qual. 13:147-169.

28. Tsutsui, T., E. Li-Chan, and S. Nakai. 1986. A simple fluorometric method for fat-binding capacity as an index of hydrophobicity of proteins. J. Food Sci. 51:1268-1272.

29. Tzaphlidou, M., E. Kounadi, I. Leontiou, P. Matthopoulos, and D.
Glaros. 1997. Influence of low doses of $\gamma$-irradiation on mouse skin collagen fibrils. Int. J. Radiat. Biol. 71:109-115.

30. Urbain, W. M. 1989. Food irradiation: the past fifty years as prologue to tomorrow. Food Technol. 43:6-92.

31. Yunginger, J. W. 1997. Food antigens, p. 50. In D. D. Metcalfe, H. A. Sampson, and R. A. Simon (ed.), Food allergy: adverse reactions to food and food additives. Blackwell Scientific Publications, Boston. 